KALEIDOSCOPE

\author{
RéKa FrIEderY* ${ }^{*}$-BaLÁZs HorváthY ${ }^{* *}$
}

\title{
The Hungarian EU Presidency- A Newcomer's Experience in a Novel Institutional Framework
}

\section{Introduction}

In the first half of 2011 Hungary held the rotating Presidency ${ }^{1}$ on top of the Council for the first time since joining the EU. The exercise of the presidential functions was influenced by the fact that the Treaty of Lisbon significantly reshaped the position of the rotating Presidency in the architecture of the European Union. The Spanish-Belgian-Hungarian Trio Presidency has been already carried out within the revised institutional framework which required a new style to accomplish the proper function of the Presidency. That means an entirely different approach which enables the successful cooperation of the country holding the presidency with the new leaders on the floor, namely with the permanent President of the European Council and with the High Representative for Foreign Affairs and Security Policy (HR).

These institutional changes effectuated by the Treaty of Lisbon as well as the Hungarian Presidency itself make sense of an analysis with respect to the new institutional model; moreover to the challenges and achievements of the Hungarian Presidency. For that reason the following article describes the institutional background along with the most important functions of the presidency, which is followed by an overview of the Hungarian Presidency's work and the main conclusions.

* Research fellow, HAS CSS Institute for Legal Studies, H-1014 Budapest, Országház u. 30. E-mail: friedery@jog.mta.hu

** Research fellow, HAS CSS Institute for Legal Studies, H-1014 Budapest, Országház u. 30; associate professor, Széchenyi István University, Deák Ferenc Faculty of Law and Political Sciences, Department of Private and Public International Law, H-9026 Egyetem tér. 1.

E-mail: bhorvathy@jog.mta.hu

This article is part of the research project "The impacts of the Lisbon Treaty on Hungarian legal order" funded by the Hungarian Scientific Research Fund (Research number: OTKA 76488).

1 The institution in question was called initially as "Presidency of Council of Ministers", nowadays the Treaty of Lisbon applies the term "The Presidency of Council configurations". The unofficial wording uses also other forms, e.g. "rotating Presidency", "Council Presidency", "EU Presidency" etc. Even if the informal terminology do not reflect on the new institutional framework set down by the Treaty of Lisbon and can lead to misunderstandings because of its easily confusable character with the European Council's permanent President, we apply the before mentioned formulations as synonyms. 


\section{The EU Presidency model after the Treaty of Lisbon}

1. In general sense, the EU presidency serves to carry out the leadership model of the European Union, ${ }^{2}$ but it is noteworthy that the EU as a "sui generis" organisation is standing out from the traditional models of international organisations regarding leadership functions. In the traditional organisations the leadership and the management functions are completed within separate institutional frameworks, however in the Community model designed by Jean Monnet these functions institutionally could not be detached from each other. Both leadership and management functions-as classic and general political leadership tasks-have fallen into the competence of the Member State holding the actual rotating Presidency. Thanks to this unique institutional approach the centre of these functions was the Council of Ministers as well as the European Council which were led by the rotating Presidency for decades.

But the tasks and competences of the Presidency were quite larger than the general leadership and management over the Community institutions. As a result of the Community's development, the expansion of its activity as well as the enlargement of its competences to new domains, the rotating Presidencies should take progressively more and more administrative and managerial tasks in hand, as a consequence of which the Presidency became a general "administrator" whilst it should also take responsibility for determining the political agenda of the EC (later of the EU). This "double undertaken", i.e. the administrative as well as the political overload of the Member State chairing the Council brought to surface several problems which could not be tackled by adequate institutional solutions until the Treaty of Lisbon. This Treaty reform has changed fundamentally the role of the rotating Presidency in view of the fact that the Lisbon Treaty has introduced new players on top of the European Union.

2. In this perspective the most substantial amendment of the Lisbon Treaty was the setting up of a permanent President of the European Council. ${ }^{3}$ The President has been appointed for a two and a half year term in a qualified majority vote of the European Council. The President's work is mostly administrative, as she or he is responsible for coordinating the work of the European Council, hosting its meetings and reporting its activities to the European Parliament after each meeting and at the beginning and end of his or her term. ${ }^{4}$ In other words most of the tasks relating to the European Council which was exercised earlier by the Member States holding the Presidency, came under the influence of the permanent President. Therefore the rotating Presidency obviously lost its power in that level. The most significant and visible change concerned the role of the Prime Minister or Head of the Member State holding the rotating Presidency. It is because, till the Treaty reform she or he was entitled to prepare and to lead the meetings as well as to coordinate the activities of the European Council but all these competences were undertaken by the new permanent President of the European Council following the Lisbon amendments.

2 In general, see: Hayes-Renshaw, F.-Wallace, H.: The Council of Ministers. London, 1997; Tallberg, J.: Leadership and Negotiation in the European Union. Cambridge, New York etc., 2006; Vörös, I. (ed.): Az EU-elnökség [The EU-Presidency]. Budapest, 2010; Westlake, M.: The Council of the European Union. London, 1999.

3 Article 15 Para. 5 of Treaty on European Union (TEU). For this position, Herman van Rompuy has been appointed in 2009 .

${ }^{4}$ Cf. with Art. 15 Para. 6 TEU 
The other essential change has occurred in the position of the rotating Presidency regarding the foreign and security policy matters. The power of the Council Presidency in this field of external policies was already touched upon by the European Political Cooperation (EPC) introduced in the ' $70 \mathrm{~s}$ and as a result, the Presidency came to give the common voice for the EC/EU at international level until the Treaty of Lisbon entered into force. Under the modified Treaty, the permanent President-not the rotating Presidency-is to provide general external representation to the Union, although these tasks and functions are shared with the High Representative of the Union for Foreign Affairs and Security Policy (HR). ${ }^{5}$ This "new-old" position which has been commonly likened to a "foreign minister" for the EU, ${ }^{6}$ gives the power in hand of a strong player. The HR is appointed by the European Council acting by qualified majority and it may end his term of office by the same procedure. Following the Treaty of Lisbon, the HL conducts the Union's common foreign and security policy and contributes by his or her proposals to the development of that policy. The position is assisted by the European External Action Service ${ }^{7}$ and the HR plays also important role within the Council of Ministers and the European Commission. Namely, she or he presides over the Foreign Affairs Council and sits in the Commission as one of its Vice-Presidents.

That "double hat" arrangement arising from the Lisbon amendments serves the institutional fusion of the foreign policy which helps to ensure the consistency of the external action at the whole Union level. At first sight, an institutional model which is able to bring the Commission's operation into line with the activity of the Council, makes a definite contribution to ensure more efficiency in the field of the external policies. However, it cannot be overlooked, that linking personally the Commission and Council together can be a point of great nicety from the legal perspective. It can be said that the High Representative has the right to propose in the field of external relations, and as the HR chairs also the Foreign Affairs Council, apart from certain exceptions, has also influence on deciding about these proposals, and finally, the Council may empower the HR in order to implement these decision. In other words, some aspect of preparation, deliberation or decision and implementation is concentrated in HR's hand. It is difficult to deny that the operation of the HR is determined by not only legal, but dominantly by political factors, and the personal association of these institutions can make the EU's political decisionmaking in the field of external policy fields more efficient. Even if it would have positive effect from the point of efficiency, the power concentration in the hands of HR can be detrimental to the normative legitimacy of EU's external action.

As regards the organizational background, it can be stated that neither the Treaty of Lisbon gives the status of "Union institution" to the presidency. The TEU refers to the

5 Article 18 TEU. The position is currently held by Catherine Ashton.

6 The predecessor for this position-frequently called as "Mrs/Mr CFSP"-was introduced by the Treaty of Amsterdam. Javier Solana held the post for ten years until he was replaced with Catherine Ashton within the new institutional framework. The term "foreign minister" can be derived from the draft European Constitution under which this position was titled "Union Minister for Foreign Affairs". The Treaty of Lisbon shaped out the institutional face identical to the rules of the European Constitution, but its title, on British initiative, has been changed.

7 The setting up of the Service was launched in December 2010. 
presidency among the rules on the Council only with laconism. According to the Treaty, the "Presidency of Council configurations", other than that of Foreign Affairs, shall be held by Member State representatives in the Council on the basis of equal rotation. ${ }^{8}$

\section{Main Functions of the EU Presidency}

\section{Leadership function: governing the Council}

As it was set out above, the Member State holding the Presidency has suffered the major power loss in relation to the role of an EU wide political leader. In this respect the Presidency is obliged to cooperate with the above-mentioned permanent President of the European Council as well as with the High Representative. Consequently, the scope of the Presidency's leadership function is already limited to the Council of Ministers.

The EU Presidency conducts and organises the operation-including the day-to-day business-of the Council. The Council configurations, Coreper and preparatory bodies of the Council are chaired by the delegate of the Member States holding the Presidency, except in cases where the leading of the body in issue falls within the competence of the HR. Among the directed bodies, the General Affairs Council is highly important for the reason that this organ is responsible for coordinating the efforts made by the Council configurations. The General Affairs Council has to deal with the horizontal questions regarding the EU institutions as well as horizontal policy matters which extend over more Council configurations' competences. Besides the General Affairs Council, also the Coreper is a crucial forum responsible for the preparation of the decisions. The Coreper is lead by the permanent representative or her/his deputy of the Member State holding the rotating Presidency. The realising of the leadership function requires the Presidency's sophisticated abilities to trouble-shooting, problem-solving, as well as consensus-making.

\section{Function of proposing: setting out the priority objectives and drawing up the agenda}

In line with the function of proposing, the Presidency is capable of influencing the main direction of the Council's work as well as the developing tendency of the whole European Union. On account of the specific institutional structure of EU, the function of proposing can be interpreted in this term rather political capacity than legal competence, because the function of proposing, from legal perspective, lies within the competence of the European Commission. The Member State holding the rotating presidency is able to determine the half year programme, to set down the chief priorities. And more concretely, the Presidency decides on the agenda of Council meetings and in cooperation with the permanent president, it may have influence on establishing the political agenda of the European Council.

In a broad view, the specification of the EU's main objectives is framed with a three level programming which sets a limit to the Presidency's playing field. The highest level is the Union's multiannual programme which establishes the fundamental tendencies. The General Affairs Council should ensure consistency and continuity in the work of the different Council configurations in the framework of this long-term multiannual programmes. ${ }^{9}$

8 Article 16 para. 9 TEU.

9 Cf. Art. 3 of European Council 2009/881/EU decision on the exercise of the Presidency of the Council. 
The 18 months programme of the Presidency "trio" marks the next level of the programming. According to the present practice, the Trio Presidency programme is worked out by the Member States of the trio, and they should present it in consolidated document at latest one month to the term of the actual trio presidency. As a final point, the half year term programme of the Member States holding the rotating presidency should fit in these before mentioned framework, i.e. in the multiannual as well as in the Trio Presidency programme. Practically, it means that the Presidency which is to hold office in the relevant period should establish draft agendas for Council meetings, for each Council configuration, scheduled for the next six-month period, showing the legislative work and operational decisions envisaged. ${ }^{10}$ These draft agendas shall be established at the latest one week before the beginning of the relevant six-month period.

In line with these general programming frameworks, the Presidency is able to exercise its capacity directly in order to determine the concrete, daily agenda of the Council, and, only implicitly, can put pressure on setting up of the agenda of the European Council. Regarding the Council's agenda, the function of proposing becomes visible in the preparation of the Council's meetings, consequently this function manifests in the activity, operation of the ministers and their staff responsible for preparing and chairing the meetings of the Council configurations. As a result of the amendments of the Lisbon Treaty, however, the Presidency's ability to put items on the agenda of the European Council has become indirect. The permanent President is responsible for setting up the agenda of the European Council, but it is required to enter into negotiation with the General Affairs Council on this issue. In other terms, the Member State holding the EU presidency can practise influence on the agenda only within these negotiations, but the content of the provisional agenda is to be finalized by the permanent President of the European Council. Nevertheless, this influence capacity of the EU presidency should not be underestimated. If the Council of Ministers cannot bring certain legislative proposal to decision, the disputed topic can be referred to the European Council in the expectation that the head of states and governments will be able to reconcile the questionable points and make a consensus at higher political level. That is why the permanent President should always take into consideration the impulses arising from the Council, namely the proposals made by the General Affairs Council which is in fact chaired by the Member State holding the actual rotating presidency. Consequently, the obligation to initiate negotiation with the General Affairs Council is not only a formal rule.

\section{Function of representation: mediation of the Council's position}

The function of representation implies tasks with internal as well as external aspects. This function means in a general approach that the EU presidency speaks for the Council in internal relations within the Union's organisation and on the other hand, the Presidency should practise also certain competences for representing at international level within the external relations.

As regards the internal side, it can be stated that the highest responsibility is undertaken by the Presidency for the co-operation with other institutions. Accordingly, the Presidency is involved in the decision-making procedures in which the Council is obliged to co-operate and consult with other institutions; moreover the daily work of the Council demands certain formal as well as informal negotiation with other bodies of the EU. More concretely, the

10 Article 2 para. 7 of Council's Rules of Procedure. Adopted by Council 2009/937/EU decision. 
Council is responsible for preparing and ensuring the follow-up to meetings of the European Council and for this reason it should confer with the Commission (besides the permanent President). Moreover, the Council bears the same consultative obligation with the Commission regarding the preparation of its six month draft agenda. ${ }^{11}$ Concerning the external representation, the Treaty of Lisbon resulted in substantial loss of power of the Member State holding the six-month long Presidency. Prior to that, the external representation on the field of foreign and security policy matters fell within the competence of the rotating EU Presidency. Contrary to that, after the Treaty reform the Member States have been relegated to background in this respect. The High Representative became the most dominant player of the foreign policy and the Member State chairing the Council is bound to close co-operation with the person holding this post.

\section{Administrative function: managing and operating the Council's work}

The administrative function refers to the most general and widest administrative tasks of the Presidency, but in all probability, the workload caused by administering the day-to-day work of the Council remains quite unknown to the publicity.

This function can be taken to mean the administrative tool behind the above described main functions. In other words the administrative function is linked subsidiarily to the other main functions, it ensures the administrative background of managerial, proposing and representative duties of the Presidency, from preparation of decisions through deliberations to their publication. It can be mentioned that the configurations of the Council meet when convened by the President (and also its members as well as the Commission may propose the meeting of the Council). ${ }^{12}$ In this respect the Presidency should synchronise the Council's schedule also with the meetings of the preparatory bodies and the Coreper. The chairing of the Council meetings includes also administrative tasks. The president of the Council configuration-in fact the minister of the Member State holding the Presidencyinitiates the voting as well as the president is required to open a voting procedure on the initiative of a member of the Council or of the Commission, if it is backed by the a majority of the Council's members. ${ }^{13}$ Among the organisational tasks of the president it can be mentioned that he or she has to check that there is a quorum when the vote is taken. In this regard the president can rely on the assistance of the General Secretariat none the worse for the complexity of the voting rules laid down by the Treaties. ${ }^{14}$

But in addition, as a consequence of the Presidency's growing administrative workload, it is generally essential to establish a harmonious cooperation between the Presidency staff and the General Secretary, because the Secretary as a neutral, professional background institution can give security for the smooth continuity of the subsequent rotating Presidencies. The Council's Rules of Procedure lays down general obligation to cooperation, since the Council shall be assisted by a General Secretariat. ${ }^{15}$ Besides that, the Secretary should undertake several technical tasks as well, for example, the Secretary organises the written decisions making procedures; it issues the passes to admission to meetings of the

11 Article 2 para. 7 of Council's Rules of Procedure.

12 Cf. with Art. 217 of Treaty on the Functioning of the European Union (TFEU).

13 Article 11 para. 1 of Council's Rules of Procedure.

14 Article 11 para. 4 of Council's Rules of Procedure.

15 Article 23 para. 1 of Council's Rules of Procedure. 
Council; or the minutes of meetings should be signed by the Secretary-General (or in case of delegation, by the Directors-General of the General Secretariat); etc.

It can be concluded that the General Secretariat is closely involved in organising, coordinating and ensuring the coherence of the Council's work. Furthermore, it is also in Council Presidency's own interest because as the experiences from the previous Presidencies' terms show, the excellent teamwork with the staff of the Secretary can give partly the clue to a successful Presidency term.

\section{The Council Presidency in Practice: the Hungarian EU Presidency}

The Spanish-Belgian-Hungarian Presidencies made "Trio Presidency" become the first "institutionalized" presidency by the Treaty of Lisbon, and which since the entry into force of the Treaty of Lisbon at the end of 2009 not only had to provide a kind of continuity for the Union, but also the Spain-Belgium-Hungary formed group had to perform next to new institutional actors, as mentioned and analysed before. As a member of the trio, Hungary's first Presidency faced challenges, which represented the largest European risk of the first half year: the indebtedness problem of the EU Member States, the unprecedented difficulties in economic situation, ${ }^{16}$ the weakening of the euro-zone and the efforts for strengthening the economic governance. Furthermore, almost as an answer to the Presidency's "Strong Europe" motto, the events regarding the "African Spring" and the Japanese earthquake had to be faced as well, not to mention the criticism and debates in the European Parliament about Hungarian internal affairs, namely about the new media law and the new constitution.

\section{Preparation of the Hungarian Presidency and the priority of the program}

The three Presidency Bureau established the so-called "EU Trio" Committee, which organized the eighteen-month-long European agenda under the direction of the presiding state. The 18 months-long cooperation of the Trio Presidency was detailed in a Trio Presidency program ${ }^{17}$ : the first part of the program, the strategic framework, consisted of main priorities and long-term goals, while the second part, the operative program gave full particulars about the first part. ${ }^{18}$ In the frame of the Hungarian Presidency, the successful arrangement of the nearly 260 Hungarian events ${ }^{19}$ was organized with the help of about 800 officials under the aegis of the Ministry of Foreign Affairs. Furthermore, to ensure the background and the close cooperation with other EU institutions, the Permanent Representation in Brussels has been strengthened and the personnel of the ministries have been increased by 225 people. As the Ministry of Foreign Affairs was responsible to coordinate the EU related work, it has grown the most.

Other changes made were that the EU State Secretariat of the Ministry of Foreign Affairs has been enlarged by three new temporary departments, and the government

16 Jose Manuel Barroso about the challenges of the Hungarian EU Presidency. In: $A z E P$ elfogadta a magyar elnökségi programot [The EP approved the presidency-program]. Brüsszel, 2011. január 19. http://bruxinfo.hu/cikk/20110119-az-ep-elfogadta-a-magyar-elnoksegi-programot. html (10.10.2011)

17 See Friedery, R.: Spanyol elnökség [Spanish Presidency]. In: Vörös (ed.): op. cit. 183.

$18 \mathrm{http}: / /$ www.eu2010.es/en/presidencia/trio/ (10.10.2011)

19 The Presidency's budget totaled HUF 23,78 billion, which is around EUR 85 million. http:// www.eu2011.hu/hu/az-elnokseg-koltsegvetese (10.10.2011) 
appointed two government commissioners, one for the operational management and another one for coordinating Hungarian government activities in connection with the EU Strategy for the Danube Region. ${ }^{20}$

\section{Main targets-main achievements}

The Hungarian Presidency put a variety of economic issues, common policies, enlargement targets into its program which was built around top four priorities:

1. growth and employment for preserving the European social model,

2. stronger Europe,

3. citizen friendly Union,

4. enlargement and neighbourhood policy. ${ }^{21 ; 22}$

1. The first above-mentioned priority of the ambitious program had the important task to make steps in the reinforcement of the economic policy co-ordination, and in connection with this Hungary launched the first European Semester, a new economic policy coordination. Already during the Belgian Presidency, a Council working group has been set up for the coordination of the Member States' economic policy, which started the discussions on creating the legal bases, the so-called six pack of the EU economic governance. The Hungarian Presidency had the main part of the work, the lion share in the negotiations, and though agreement was reached in the March Ecofin ${ }^{23}$, the Parliament postponed the vote because they could not agree about an important voting technique until the end of the Hungarian presidency.

Still in this priority-group, the presidency introduced a new issue, namely to start EU discussion about European-level measures in the field of integration of the around 12 million Roma-people of the EU. It was not all without reason because Hungary has significant number of Roma people, too. The success was reached thanks to the integration of the sometimes quite diverse positions of the Member States. Thus, the Council of Social Ministers adopted a final document about the Framework for Roma Strategy, which was based on the Commission's Communication "An EU Framework for National Roma Integration Strategies up to 2020" of 5 April 2011. Council conclusions have been reached about the EU-framework of national Roma integration strategies until 2020, where Member States work out their action programmes that will be monitored annually by the Commission and the results reported to the Parliament and the Council.

A major step could be made regarding competition policy, in the issue of the unitary patent. After decades-long debates, again with the help of intense negotiation, the Presidency could find thirteen more Member States next to the original twelve who had initially requested for the enhanced cooperation. With twenty-five members, an agreement could be sealed on allowing in the future (from 2014) the use of a new European patent system.

2. One of the main issues of the "Stronger Europe" priority, and personally important to Hungary, was the European strategy on the development of the Danube-region, whose model was the successful Baltic Sea Strategy. As it could be finished in time according to the preliminary program negotiations, the result of several years of preparatory work and

$20 \mathrm{http} / /$ www.eu2011.hu/hu/magyar-elnokseg-strukturaja (10.10.2011.)

${ }^{21}$ Program-Az Európai Elnökség Tanácsának Magyar Elnöksége [Program-The Hungarian Council Presidency]. 2011. január 1-június 30. A Magyar Köztársaság Külügyminisztériuma, 2011.

$22 \mathrm{http} / / /$ www.eu2011.hu/hu/magyar-elnokseg-prioritasai (2011.10.10.)

23 Economic and Financial Affairs Council, see more Vörös (ed.): op. cit. 226. 
consultations paid off, hence it has been approved at the closing summit meeting. Obviously, the adoption strengthens the future role of the macro-regional approach, too: the Council conclusion approving the strategy called on the Member States to work with the Commission to continue the improvement of the macro-regional co-operation, specifically referring to the Adriatic and the Ionian Sea region as the future target area of next macro-regional cooperation. $^{24}$

In the field of energy policy, it was the first time that during a Presidency energy debate on the level of heads of states and governments took place. The Energy Council adopted conclusions on energy infrastructure priorities, on the overview of energy efficiency directive, on the realization of internal market completed by 2014. In June, Member States approved a draft compromise proposal presented by the Hungarian Presidency, aiming to close the negotiations with the European Parliament on the Regulation on energy market integrity and transparency. The Council also started negotiations on the EU External Energy Policy thus for the better coordination of EU and Member States' external energy policies.

Also, an extraordinary Energy Council meeting was held in March, where the challenges of the Japanese nuclear developments, and as its consequences the issue of energy security, global energy sector, as well nuclear energy was discussed. Thanks to the flexible reaction of the Presidency, after two months work the adoption of nuclear stress test criteria for the European nuclear plants could be agreed.

3. Regarding citizen-friendly Union, the Council approved the regulation on the European Citizens' Initiative, with detailed conditions under which citizens can take the initiative at the European Commission to make legislative proposal towards a joint EU action.

Another issue was the Schengen membership of Romania and Bulgaria. For Hungary, it was another personally very important target to reach. However, some Member States were not convinced, and hesitated about their preparedness of joining the Schengen-area, therefore only (or at least) a political declaration could be achieved about the technical preparedness of these two states.

We should mention the important steps made during this Presidency toward the Common European Asylum System, with the amendment of the long-term residence directive, which extended the scope of the directive to beneficiaries of international protection and with the compromise achieved with the European Parliament regarding the qualification directive (except for one horizontal political question, the correlation tables). ${ }^{25}$

4. As for enlargement and neighbourhood policy, next to holding the chair on the Western Balkans Forum, the other main priority, the closing of the accession negotiation with Croatia was successful. Also, steps were made in the accession negotiations with Iceland, namely four chapters were opened and two were already temporarily closed. In connection with the North-African events, after the Lisbon Treaty the Hungarian presidency was the first Presidency when the European Foreign Service as the foreign policy decisionmaking body of the EU has come into action: on this ground the foreign minister of the

${ }^{24}$ See Horváthy, B.: A Duna Régió Stratégia a magyar uniós elnökség tükrében [The Danube Strategy in the Light of the Hungarian EU Presidency]. Jogi iránytü, 2011/3. on http://www.mta-ius. hu/jogi_iranytu/iranytu.html (2011.10.10.)

${ }^{25}$ See more Friedery, R.: A huzamos tartózkodási jogállásról szóló 2003/109/EK irányelv hatályának kiterjesztése a nemzetközi védelmet élvező személyekre [Amending Council Directive 2003/109/EC to extend its scope to beneficiaries of international protection]. Jogi Iránytü, 2011/2. on http://www.mta-ius.hu/jogi_iranytu/iranytu.html 
actual Presidency has only a complementary and supporting role. Besides this, the Presidency has activated, on Member States' request, the EU Civil Protection Mechanism in co-operation with the Commission for Libya and for Japan, which supports and facilitates the mobilisation of emergency services to meet the immediate needs of countries. ${ }^{26}$

Thus, as we can observe, one must conclude that in every top four declared priorities a very important issue could be achieved. ${ }^{27}$

\section{Conclusion}

At first sight, the presentation of the institutional background and the functions of the Presidency suggests that with the Lisbon Treaty generated reform the Presidency loses its influence in the leading role for the benefit of the permanent president and the High Representative of Foreign Affairs and Security Policy.

There is no doubt that during the exercise of specific functions, for example in the case of the external representation tasks, the loss of role of the Presidency towards the direction of the Foreign Service is perceptible, but on the whole the overall change in the position of the Presidency should rather be evaluated more as a shift in emphasis.

The realization of the Spanish-Belgian-Hungarian Trio Presidency clearly showed that this requires a new kind of role-perception from the Member States holding the Presidency which is based-and thus is a key to success-on the effective co-operation of the new institutional actors.

Regarding the concrete results of the Hungarian presidency, as objective standards, the completed cases, the legislation adopted can be mentioned. In this regard, it can be stated that in the difficult period of the EU, in total 103 files have been solved, out of these 43 OLP legislative files with the European Parliament (20 in 1st reading, 6 in 2nd reading and 1 in 3rd reading) and 60 Council or Presidency conclusions have been adopted. ${ }^{28}$

Although because of the European Parliament's summer break the sealing of the legislative six-pack and the vote shifted to the Polish Presidency, but can be mostly regarded as one of the largest Hungarian results, because a large part of the Council agreement as well the Parliament agreement was achieved during the Hungarian Presidency.

Another big success was that despite some anti-enlargement Member States, the accession of Croatia has been completed which is, regarding the stability of the Western Balkans, a major step forward strengthening the future European role of Western Balkans. Although being important for the Presidency, in the issue of the Schengen enlargement no political decision was taken, but the completion of the technical preparations could be recorded. Other success of great importance was that a new important issue appeared on the European agenda, namely the economic and social integration of the significant number of Roma living in Europe.

It should be pointed out that diplomatically it has been seen as a great success when only the Hungarian Embassy operating in Tripoli represented the European Union, and co-

${ }^{26}$ N. Rózsa, E.: Libya and the Hungarian EU Presidency. Gyorselemzés, 2011/14. on http:// www.hiia.hu/pub/displ.asp?id=TVYBGH (2011.10.10.)

$27 \mathrm{http}: / / \mathrm{www} . \mathrm{consilium}$.europa.eu/moresearchresultsregistry? search=council\%20 conclusion\&lang=en

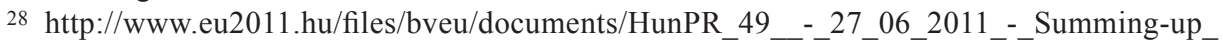
the_Hungarian_Presidency_0.pdf 
ordinated between the Member States during the Libya events. We should add that the Presidency put great emphasis on portraying cultural diversity, to this end, it organized many high-quality cultural programs, setting an example for future presidencies, because before no other presidency organized so much events during a half-year period.

Next to the positive achievements it should be also noted that the postponement of the second Eastern Partnership summit (the EU with Ukraine, Belarus, Moldavia, Armenia, Georgia and Azerbaijan), which was scheduled as the main foreign-policy event of the Presidency, is seen by many as a failure. An explanation for this can be that around the time a culmination of other unexpected events such as the African ones with their effects were in the centre of the EU attention. We can add to this that it cannot be regarded as a disappointment, because the emphasis was on other events with worldwide importance (including the G8 or the OECD summit). In addition, another failure seen was the common agricultural policy, where no agreement could be achieved in contrast to the cohesion policy, where Presidency conclusions set up the future principles of the Common Agricultural Policy.

Of course, every first-time Presidency's plan is to show off some impressive results at the end of its half-year period. In this case, the first Hungarian presidency responded well to the unexpected events and managed to reach some personally important targets, too.

However, not only the Hungarian but the first Trio Presidency performed well, too: often the preparatory work made by one Presidency resulted the success of the following presidency's (as in the case of the regulation on the European Citizens' Initiative (ECI) where the major part of the preparatory work was done during the Belgian Presidency, but the Hungarian Presidency signed it, or in the case of the six-pack, which was closed during the Polish presidency and also the vote took place thanks to the work of the Hungarian Presidency), thereby ensuring for which the Trio Presidency was established: continuity for the EU. 
